\title{
Coming full circle: an impressive case of Crohn's disease
}

\author{
Donevan Westerveld, ${ }^{1}$ Atish Patel, ${ }^{2}$ Walter Drane, ${ }^{3}$ Sarah Glover ${ }^{4}$
}

${ }^{1}$ Department of Internal Medicine, University of Florida College of Medicine, Gainesville, Florida, USA ${ }^{2}$ University of Florida College of Medicine, Gainesville, Florida, USA

${ }^{3}$ Department of Radiology, University of Florida College of Medicine, Gainesville, Florida, USA

${ }^{4}$ Department of

Gastroenterology, University of Florida College of Medicine, Gainesville, Florida, USA

\section{Correspondence to} Donevan Westerveld, dwesterveld@ufl.edu

Accepted 30 January 2016

\section{DESCRIPTION}

A young man in his 20 s with a 1 -year history of Crohn's disease, presented with severe abdominal pain, constipation, vomiting, 20 pound weight loss and 5-6 persistent watery stools per day. Three months prior to his presentation, the patient had received treatment with Humira, however, due to the loss of his job and lack of finances, he had not received subsequent treatment. Laboratory values were significant for an elevated C-reactive protein of $25 \mathrm{mg} / \mathrm{L}(0-4.9 \mathrm{mg} / \mathrm{L})$, and an erythrocyte sedimentation rate of $16 \mathrm{~mm} / \mathrm{h}$. An abdominal/pelvic contrast-enhanced MRI enterography revealed multiple enteroenteric fistulas and distention of multiple loops of small bowel leading to compression of the stomach (figure 1). Subsequently, the patient underwent a laparoscopic ileocolectomy with ileo ascending colonic anastomosis, takedown of enteroenteric fistula and a stricturoplasty-type repair of the small bowel.

Fistulising Crohn's disease may cause significant morbidity and mortality if not treated effectively. Since the introduction of antitumor necrosis factor chimeric antibodies in the treatment of Crohn's nearly 15 years ago by Derkx et al, ${ }^{1}$ biologics have gained an important place in the treatment of inflammatory bowel disease. Moreover, the ACCENT II trial demonstrated a higher rate of closure of fistulas in those treated with infliximab versus placebo. ${ }^{2}$ We present a case of a young man with significant enteroenteric fistulas leading to a closed loop of small bowel, bowel distention

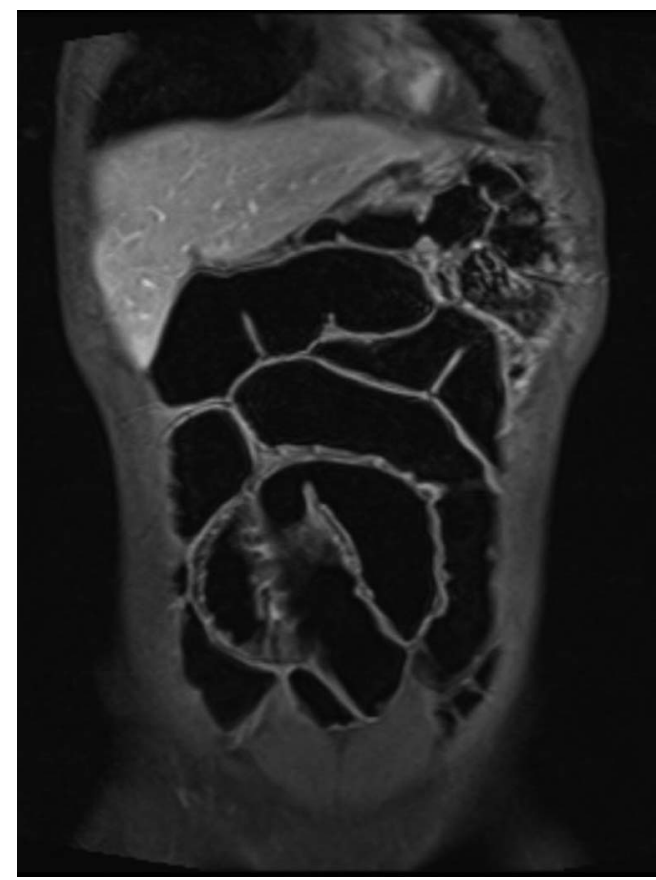

Figure 2 T1-weighted (volumetric interpolated breath-hold examination) contrast-enhanced MRI of the abdomen and pelvis demonstrating significantly dilated loops of bowel.

(figure 2) and compression of the stomach. With proper medical and surgical management, the patient's symptoms improved and he is currently undergoing close medical follow-up.
To cite: Westerveld $D$, Patel A, Drane W, et al. BMJ Case Rep Published online: [please include Day Month Year] doi:10.1136/bcr-2015214132

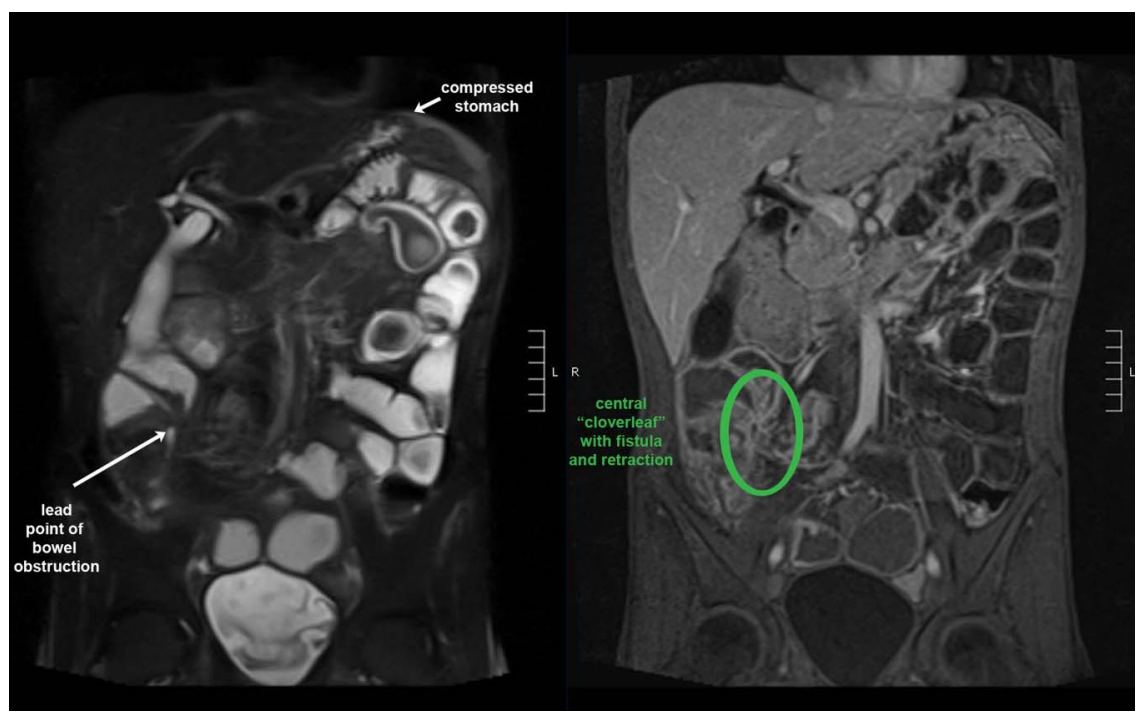

Figure 1 T2-weighted (half-fourier acquisition single-shot turbo spin-echo) contrast-enhanced MRI of the abdomen and pelvis showing the lead point of bowel obstruction in addition to the centre of obstruction with fistula formation and retraction. Compression of the stomach may be noted. 


\section{Learning points}

- Crohn's disease is an evolving disease that may cause significant morbidity and even mortality if proper medical management is not implemented.

- Fistulising Crohn's disease may lead to significant enteroenteric fistulas causing a closed loop system of the small intestine and compression of the stomach or surrounding organs. In a patient with a history of undermanaged or non-managed Crohn's disease, who presents with abdominal pain, constipation and postprandial vomiting, one must be concerned for intra-abdominal fistulas.

- MR enterography has revolutionised the imaging of the small bowel, particularly in Crohn's disease, and is preferred over CT because of both its sensitivity to contrast and its lack of radiation.
Contributors DW, AP, WD and SG contributed to this project as a team; portions were written and edited by each member of the team multiple times. SG, the attending physician, gave the final approval to this work.

Competing interests None declared.

Patient consent Obtained.

Provenance and peer review Not commissioned; externally peer reviewed.

\section{REFERENCES}

1 Derkx B, Taminiau J, Radema S, et al. 'Tumour-necrosis-factor antibody treatment in Crohn's disease'. Lancet 1993;342:173-4.

2 Sands BE, Anderson FH, Bernstein CN, et al. 'Infliximab maintenance therapy for fistulizing Crohn's disease'. N Engl J Med 2004;350:876-85.

Copyright 2016 BMJ Publishing Group. All rights reserved. For permission to reuse any of this content visit

http://group.bmj.com/group/rights-licensing/permissions.

BMJ Case Report Fellows may re-use this article for personal use and teaching without any further permission.

Become a Fellow of BMJ Case Reports today and you can:

- Submit as many cases as you like

- Enjoy fast sympathetic peer review and rapid publication of accepted articles

- Access all the published articles

- Re-use any of the published material for personal use and teaching without further permission

For information on Institutional Fellowships contact consortiasales@bmjgroup.com

Visit casereports.bmj.com for more articles like this and to become a Fellow 